\title{
COPROPHILOUS FUNGAL COMMUNITY OF WILD RABBIT IN A PARK OF A HOSPITAL (CHILE): A TAXONOMIC APPROACH
}

\author{
(Comunidades fúngicas coprófilas de conejos silvestres en un parque \\ de un Hospital (Chile): un enfoque taxonómico)
}

\author{
Eduardo Piontelli, L, Rodrigo Cruz, C \& M.Alicia Toro .S.M. \\ Universidad de Valparaíso, Escuela de Medicina \\ Cátedra de micología, Casilla 92 V Valparaíso, Chile. e-mail <eduardo.piontelli@ uv.cl >
}

Key words: Coprophilous microfungi,wild rabbit, hospital zone, Chile.

Palabras clave: Microhongos coprófilos, conejos silvestres, zona de hospital, Chile

\begin{abstract}
During year 2005-through 2006 a study on coprophilous fungal communities present in wild rabbit dung was carried out in the park of a regional hospital ( $V$ Region, Chile), 21 samples in seven months under two seasonable periods (cold and warm) being collected. Sixty species and 44 genera as a total were recorded in the sampling period, 46 species in warm periods and 39 in the cold ones. Major groups were arranged as follows: Zygomycota (11,6 \%), Ascomycota (50\%), associated mitosporic genera (36,8 \%) and Basidiomycota $(1,6 \%)$. Ascomycetes genera having the highest occurrence were: Chaetomium (5), Saccobolus and Sordaria (3) Podospora, Schizothecium and Sporormiella (2). Constant and dominant species were : Chaetomium cuniculorum, $\mathbf{C h}$. murorum, Coprinus spp., Iodophanus carneus, Pilaira anomala, Schizothecium tetrasporum, Sordaria humana, Sporormiella teretispora and Stilbella fimetaria. Under a taxonomic approach focused on the majority of meiosporic fungi (Ascomycota), the presence of new records of fungi for Chile is emphasized: Fusariella hughesii, Neurospora caulospora, Pleuroascus nicholsonii, Rhytidospora bispora, Saccobolus globuliferellus, among others.
\end{abstract}

\section{INTRODUCTION}

Coprophilous fungi are usually associated with herbivore dung which may serve as a growth factor for many kinds of microorganisms which as a whole (that together) play an important role in the ecosystem, recicling the nutrients contained in animal faeces. Fungal dung

\section{RESUMEN}

Durante los años 2005-2006 se efectuó un estudio de las comunidades fúngicas coprófilos en excementos de conejos silvestres en un parque de un hospital regional (V Región, Chile), colectándose 21 muestras en 7 meses en 2 períodos estacionales (fríos y cálidos). Un total de 60 especies y 44 géneros fueron detectados en el período de muestreo, 46 especies en los períodos cálidos y 39 en los fríos. La distribución de los grandes grupos fue: Zygomycota(11,6\%), Ascomycota (50\%), géneros mitospóricos asociados (36,8 \%) y Basidiomycota (1,6 \%). Los géneros de ascomycetes con mayor frecuencia de especies fueron: Chaetomium (5), Saccobolus y Sordaria (3) Podospora, Schizothecium y Sporormiella (2).Las especies constantes y dominantes fueron: Chaetomium cuniculorum, Ch. murorum, Coprinus spp., Iodophanus carneus, Pilaira anomala, Schizothecium tetrasporum, Sordaria humana, Sporormiella teretispora y Stilbella fimetaria. Bajo un enfoque taxonómico orientado hacia la mayoría de los hongos meiosporicos (Ascomycota), se destaca la presencia de nuevos registros para Chile: Fusariella hughesii, Neurospora caulospora, Pleuroascus nicholsonii, Rhytidospora bispora, Saccobolus globuliferellus, entre otros.

inhabitant is a diverse and interesting special group member including all classes of the Kingdom fungi ranging from the Zygomycota, Ascomycota (and their relatives) to Basidiomycota (Furuya \& Udagawa, 1972;Wicklow, 1981; Valdoserra \& Guarro, 1992; Richardson, 2001). Their universal distribution is influenced by the presence of herbivores in an area, types of vegetation, kind of dung, climatic conditions and latitudinal environmental gra- 
dients. However many of these coprophilous fungi have a wide ecological range and low preferences for particular herbivore dung substrate (Lunqvist 1972; Richardson, 1972; Wicklow, 1975; Tisdall \& Oades, 1982; Caretta et al., 1994).

Coprophilous fungi are popular subjects for study, but little work has been done in Chile in their particular geographic zone, in which diversity and distribution of rare species and undescribed fungi, new for science, are apparently common (Spegazzini, 1921; Lazo, 1979; Undagawa,1980; Piontelli et al., 1981-1997; Muroi \& Undagawa, 1984; Valdoserra \& Guarro, 1988, 1994).

Some of these authors focused on special taxonomic groups from many habitats and type of dung, however scarce data are available from places where dung of wild rabbits are highly affected by human activity such a hospital zone.

The aim of this work was to obtain data about the richness in species of coprophilous fungi (especially Ascomycota and related taxa) in dung of these Lagomorphs, through a seven- month study in an anthropogenic soil in a park of a hospital, and some comments on the taxonomic and phylogenetic literature contribution related to the most detected meiosporic fungi.

\section{MATERIALS AND METHODS}

a) Basic characteristics of place. The Peñablanca Hospital (V Región, Chile, $33^{\circ}$ S.Lat. and $72^{\circ} 30^{\prime}$ Long. W, at $30 \mathrm{~km}$ from Valparaiso city), is enclosed in a 20 hectare park. The vegetation consists of several grasses (mainly species of Avena, Lolium, Cynodon, Hordeum, Bromus and Poa) and a wooded area having mostly species of: Pinus, Acacia, Eucalyptus, Populus, Cupressus, Jubaea and Peumus. The city (Villa Alemana) has about 100.000 inhabitants with a typical template warm climate, with winter rainfall $(360 \mathrm{~mm}$ a year) and a prolonged dry station (7-8 month).

b) Samples and identification. A total of 21 samples were collected in sterile plastic bags from 3 different sites in a $200 \mathrm{~m}^{2}$ area, since May 2005 through April 2006 (May, June, July, August, January, March and April), 3 samples each month. In the laboratory the samples were placed (duplicate) in one layer in 6 sterile Petri dishes $(10 \mathrm{~cm})$ with two sheets of sterile moist paper towels on their bases. Before incubation plates were kept at $-20^{\circ} \mathrm{C}$ for $24 \mathrm{hr}$ to avoid the presence of acari. Each plate was then incubated at $19-25^{\circ} \mathrm{C}$ room temperature under natural day and night regimes for 40 days. Substrate moisture was maintained by the periodic addition of sterile distilled water (as necessary). Cultures were examined under a dissecting microscope for fungal fructification at 5,10,20,30,40-day intervals.

Developed fungi were transferred to glass slides and stained with lactophenol cotton blue and sealed with nail-varnish before their observation at low and high magnification. Some microfungi were further cultivated on special identification media according to specific monographies. Species occurring more than once over the 6 Petri dishes were counted as one occurrence (only presence - absence). To get an approximate quantitative estimate on the occurrence frequency of a taxa in each sample, the former was marked with one or several signs (x): low presence(x), medium (xx) and high presence (xxx). Most morphometric data on Ascomycota were recorded directly on samples collected from the coprophilous substrate by using water or lactophenol preparations. For identification of fungi, the following literature was generally used: van Brumelen, 1967; Mirza \& Cain, 1969; Ellis, 197176; Lundqvist, 1972; Bezerra \& Kimbrough, 1975; Bell,19832005; Seifert et als, 1983; Ellis \& Ellis,1988; Domsch et al., 1993 (see further references in text for more details).

\section{RESULTS}

A total of 60 species and 44 genera collected from dung of wild rabbits (Oryctolagus cuniculi) were recorded in the sampling period, the latter being distributed under the following major taxonomic groups: Zygomycota (11,6 $\%)$, Ascomycota (50\%), associated mitosporic genera (36,8 \%) and Basidiomycota (1,6 \%) (Table 1). Ascomycetes genera having highest frequency of species were: Chaetomium (5), Saccobolus and Sordaria (3) Podospora, Schizothecium and Sporormiella (2). Among the 14 genera present in cold months, Chaetomium trigonosporum, Cheilimenia sp., Neurospora calospora (Fig.2,7-2,7a), Podospora appendiculata, Sporormiella teretispora (Fig. 2,10) and Trichodelitschia munkii (Fig. $1,6)$, were the only genera developed, whereas out of the 15 genera present in warm months: Coprotus sexdecimsporus (Fig.1,3), Lasiobolus intermedius (Fig.2,8), Rhytidospora bispora (Fig.1,2), Saccobolus globuliferellus (Fig.3,15) y Thelebolus stercoreus (Fig. 3,13), did developed only in that period (Table 1). Among the existing taxonomic groups, 46 species were detected in warm climates and 39 in cold months.

Constant and dominant species present among 5 to 7 within the sampling months were: Chaetomium cuniculorum (Fig.3,16 -3, 16a), Ch. murorum, Coprinus spp., Iodophanus carneus, Pilaira anomala, Schizothecium tetrasporum (Fig 2,11-2,11a), Sordaria humana (Fig.3,173,17a), Sporormiella teretispora and Stilbella fimetaria (Table 1).

Frequent species (among 3 to 5 within the sampling months) were mainly ascomycetes: Ascobolus sp. (Fig.1,5), Chaetomium elatum, C. bostrichodes, Gymnoascus reessii (Fig. 1,4), Pleuroascus nicholsonii (Fig. 2,9-2,9a), 
Table 1. Coprophilous fungi recorded from wild rabbit dung in a park of a hospital (V Region, Chile)

\begin{tabular}{|c|c|c|c|c|c|c|c|}
\hline \multirow[b]{2}{*}{ Fungal taxa } & \multicolumn{4}{|c|}{ Cold period } & \multicolumn{3}{|c|}{ Warm period } \\
\hline & 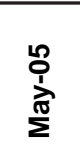 & $\begin{array}{l}\stackrel{1}{0} \\
\stackrel{d}{d} \\
\stackrel{5}{5}\end{array}$ & $\stackrel{\substack{0 \\
⿱ 亠 乂}}{\overline{1}}$ & 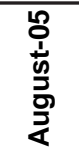 & $\begin{array}{l}0 \\
0 \\
\frac{1}{2} \\
\frac{1}{d} \\
n\end{array}$ & $\begin{array}{l}0 \\
0 \\
\frac{1}{0} \\
0 \\
\frac{0}{\Sigma} \\
\Sigma\end{array}$ & $\frac{0}{\frac{1}{1}}$ \\
\hline Alternaria alternata (Fr.) Keissl. complex & & & $x$ & & & $x$ & \\
\hline Ascobolus sp. (Sec. Sphaeridiobolus ) & $\mathbf{x}$ & & & & & $\mathbf{x}$ & $\mathbf{x}$ \\
\hline Aspergillus candidus Link & & & $\mathbf{x}$ & $\mathbf{x}$ & & $\mathbf{x}$ & \\
\hline Aspergillua niger van Thieghem var. niger & & & & & $\mathbf{x}$ & & \\
\hline Aspergillus ustus (Bain.) Thom \& Church & & & & & & $\mathbf{x}$ & \\
\hline Aspergillus versicolor (Vuill.) Tiraboschi & & & & & & $\mathbf{x}$ & \\
\hline Chaetocladium brefeldii Tiegh. \& G. Le Monn. & & $x$ & & & & & $\mathbf{x}$ \\
\hline Chaetomella acutiseta var. nigra Sutton \& Sarbhoy & $\mathbf{x}$ & $\mathbf{x}$ & $\mathbf{x}$ & $\mathbf{x}$ & $\mathbf{x}$ & & \\
\hline Chaetomium bostrichodes Zopf. & $\mathbf{x}$ & $\mathbf{x}$ & & & & $\mathbf{x}$ & $\mathbf{x}$ \\
\hline Chaetomium elatum Kunze & & & & $\mathbf{x}$ & $x$ & $\mathbf{x}$ & $\mathbf{x}$ \\
\hline Chaetomium cuniculorum Fuckel & $\mathbf{X X X}$ & $\mathbf{X X}$ & $\mathbf{X X}$ & $\mathbf{x x x}$ & $\mathbf{x x x}$ & $\mathbf{x x x}$ & $x x x$ \\
\hline Chaetomium murorum Corda & $\mathbf{x x}$ & & $\mathbf{x}$ & $\mathbf{x x}$ & $\mathbf{x}$ & $\mathbf{x X}$ & $\mathbf{x x}$ \\
\hline Chaetomium trigonosporum (Marchal) Chivers & & & & $\mathbf{x}$ & & & \\
\hline Cheilimenia sp. & & $\mathbf{x}$ & & & & & \\
\hline Chladorrhinum faecundissimum Sacc. \& Marchal & $\mathbf{X X}$ & $\mathbf{x}$ & & & & & \\
\hline Cladosporium cladosporioides (Fres.) de Vries & $\mathbf{x}$ & $\mathbf{x}$ & & & & & \\
\hline Clonostachys rosea f. rosea Schroers et al. & & & & & & $\mathbf{x}$ & \\
\hline Coprinus spp. & $\mathbf{x}$ & $\mathbf{x x}$ & $\mathbf{x}$ & $\mathbf{x x}$ & $\mathbf{x x}$ & $\mathbf{x x}$ & $\mathbf{x}$ \\
\hline Coprotus sexdecimsporus (Cr. \& Cr.) Kimbr. & & & & & & & $\mathbf{x}$ \\
\hline Doratomyces stemonitis (Pers. : Steud.) Morton \& G.Smith & & $\mathbf{x}$ & & & $\mathbf{x}$ & & \\
\hline Fusariella hughesii Chabelska-Frydman & & & $x$ & $x$ & $\mathbf{x}$ & & \\
\hline Neurospora calospora (Mouton) García, Stchigel \& Guarro. & & $\mathbf{x}$ & & & & & \\
\hline Gymnoascus reessii Baranetzky & & & & $\mathbf{x}$ & & $\mathbf{x}$ & $\mathbf{x}$ \\
\hline Harzia verrucosa (Togn.) H-Jechová & & & & & & $\mathbf{x}$ & \\
\hline Iodophanus carneus (Pers.:Fr.) Korf. apud Kimb.\& Korf & & & $\mathbf{x x}$ & $\mathbf{X X}$ & $\mathbf{X X}$ & $\mathbf{x X}$ & $\mathbf{x x}$ \\
\hline Lasiobolus intermedius Bezerra \& Kimbrough. & & & & & & $\mathbf{x}$ & $\mathbf{x}$ \\
\hline Melanospora zamiae Corda & & & & $\mathbf{x x}$ & & $\mathbf{x}$ & \\
\hline Monacrosporium bombicodes (Drechsler) Subram. & & & & & & $\mathbf{x}$ & \\
\hline Mucor hiemalis Wehmer & $x$ & $x$ & & & & $x$ & $x$ \\
\hline Mucor plumbeus Bonord. & & & & & $\mathbf{x}$ & $\mathbf{x x}$ & \\
\hline Myrothecium carmichaelii Grev. & & $\mathbf{x}$ & & $\mathbf{x}$ & & $\mathbf{x}$ & $\mathbf{x}$ \\
\hline Myrothecium verrucaria (Alb. \& Schw.) Ditm. :Fr. & & & & & & $\mathbf{x}$ & \\
\hline Neurospora calospora (Mouton) García, Stchigel \& Guarro. & & $\mathbf{x}$ & $\mathbf{x}$ & & & & \\
\hline Ochroconis tshawytschae (Doty \& Slater) Kiril. \& All-Achmed & & & & & & $\mathbf{x}$ & \\
\hline Oedocephalum pallidum (Berkeley \& Broome) Const. & & & & & $\mathbf{x}$ & & \\
\hline Papulaspora sp. & & & & & & $\mathbf{x}$ & \\
\hline Pilaira anomala (Cesati) Schröter & $x x x$ & $\mathbf{x x}$ & $\mathbf{x x}$ & $x x x$ & & $\mathbf{x}$ & $x$ \\
\hline Pilobolus kleinii van Tieghem & $\mathbf{x}$ & $\mathbf{x}$ & & & & & \\
\hline Piptocephalis freseniana de Bary & & $\mathbf{x}$ & $\mathbf{X X X}$ & $\mathbf{X X}$ & & & \\
\hline Pleuroascus nicholsonii Massee \& Salmon & & & & $\mathbf{x x}$ & $\mathbf{X X}$ & $\mathbf{X X}$ & \\
\hline Podospora appendiculata Awd. :Niessl. & & $\mathbf{x}$ & & & & & \\
\hline Podospora perplexens (Cain) Cain & & $\mathbf{x x}$ & $\mathbf{x x}$ & $\mathbf{x}$ & & $\mathbf{x x}$ & \\
\hline Rhytidospora bispora Krug \& Jeng & & & & & & $\mathbf{x}$ & $x$ \\
\hline
\end{tabular}


Table 1. Continued

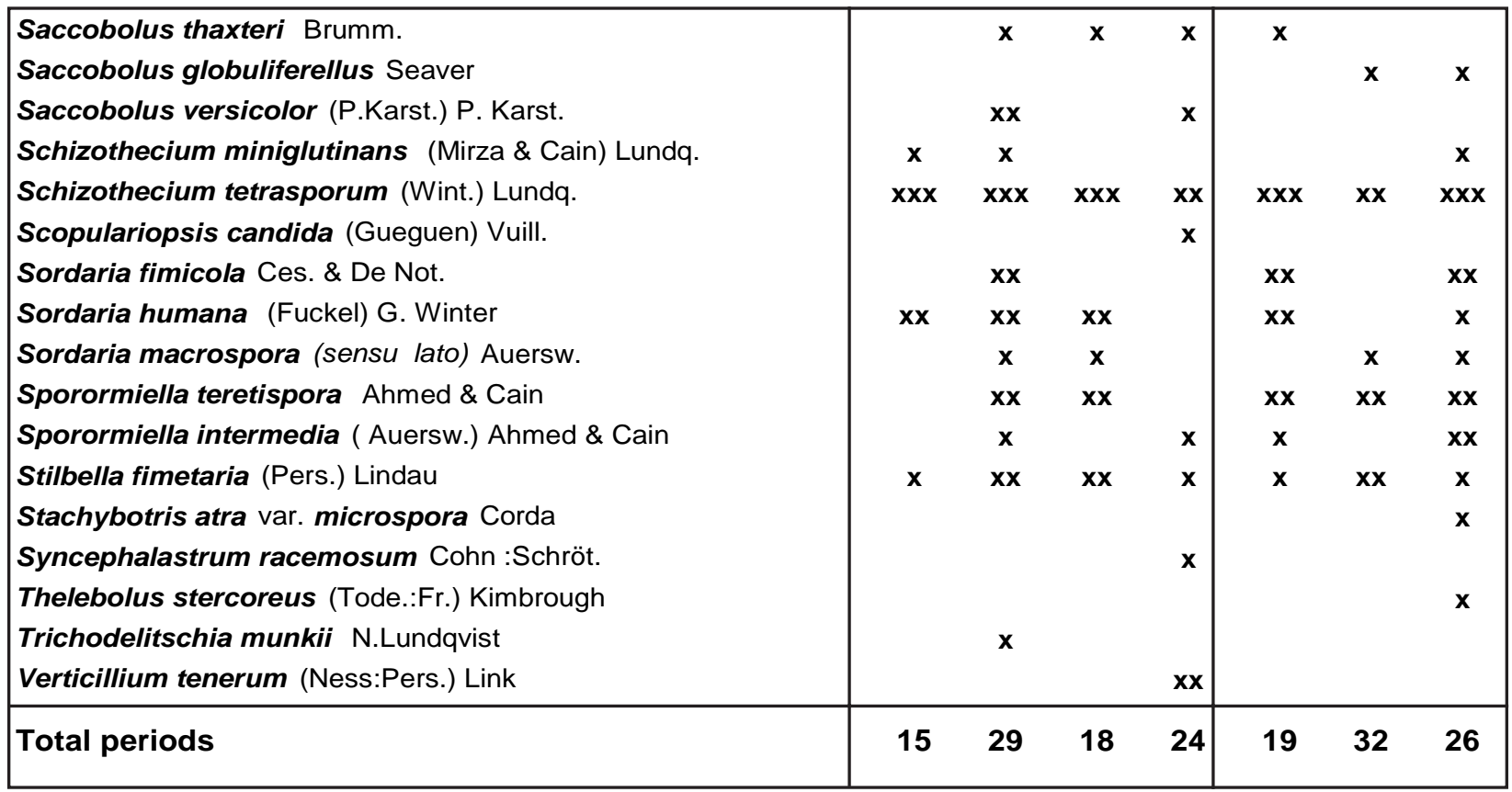

P. perplexens (Fig. 2,12-2,12a), Saccobolus thaxteri (Fig.3,14), Schizothecium miniglutinans, Sordaria fimicola y $\boldsymbol{S}$. macrospora, together with 4 anamorphic taxa: Aspergillus candidus, Chaetomella acutiseta var. nigra, Fusariella hughesii (Fig.3,18-3,19), Myrothecium carmichaelii and Mucorales such as Mucor hiemalis y Piptocephalis freseniana (Fig. 3,20)(Table 1).

Richness species in rabbit dung exhibited a 21.5 average in cold periods and 25,6 in warm periods, June and March showing the highest diversity (Table 1).

The only member of the genus Ascobolus was unable to be identified as to the species level according to the taxonomic information available and its characteristics were: yellow sessile apothecia, emarginated, 750-1300 $\mu \mathrm{m}$ diam., asci clavate to saccate (190-240 x 55-80 $\mu \mathrm{m})$, ascospores(8) (27-30 x 24-27 $\mu \mathrm{m})$, globose, becoming grayish to reddish with time, smooth to finely granulate epispores (Fig. 1.5).

Sporadic or low frequency species (in 1 or 2 of the sampling months) were the most dominant reaching as far as 34 taxa in both periods (55.7\%): Chladorrhinum faecundissimum, Lasiobolus intermedius, Melanospora zamiae, Mucor plumbeus, Pilobolus kleinii, Rhytidospora bispora, Saccobolus versicolor y S.globuliferellus are the most remarkable (Table 1).

Despite the restricted conditions in the woody area under study, the sampling zone and the scarce variety of present herbivores in the habitat, a high richness of coprophilous as well as geophilic species and those related to vegetal debris could be achieved, what made it possible to get new records for Chile : Chaetomium cuniculorum, Chaetomella acutiseta var. nigra, Fusariella hughesii, Neurospora caulospora, Pleuroascus nicholsonii, Podospora perplexens, $P$. appendiculata, Rhytidospora bispora, Saccobolus globuliferellus, S. taxtieri, Sporormiella teretispora, Trichodelitschia munkii.

\section{DISCUSSION}

In the 21 samples, the record of 60 species and 44 genera of coprophilous fungi in the wild rabbits dung is somewhat similar in the richness of species that has been described in other geographic places of the world (Harper \& Webster, 1964; Wicklow \& Moore, 1974; Rhichardson, 2001), showing no greater differences from the overall pattern of many studies on fungal diversity, reflecting at the same time that in the community (coproma), a low number of species represents the majority (dominance and constancy in the time) within many types of herbivore dung. In our case, a near number of $60 \%$ were integrates by communities appeared mostly sporadically or rarely frequently in time (Christensen, 1981; Angel \& Wicklow, 1983, 1992; Rhichardson, 2001).

The structure and composition of the community can differ as regards kind of habitat, climatic, latitudinal factors and incubation temperature (Larsen, 1971; Wicklow \& Moore, 1974). Yocom \& Wicklow (1980), based on rabbit dung related the increase in the composition of the community to the quantity of precipitations. A situation 
that in our case did not exhibit major differences in dominant and constant species yet a higher relative quantity in warm months than in the cold ones (Table 1 ), noting that rain period appears generally at the end of autumn and in winter season. However, in warm periods, common morning mists can supply a suitable environmental humidity in the sampling area. Richness of species seems to be always more abundant in lagomorphs dung than in ruminants (Richardson, 2001;Wicklow et al., 1980), but this situation is closely related mainly to the number of samples together with the patient and constant observation of the incubated plates. In our study we did not pretend to make a quantitative assessment of diversity and species richness but rather a primary estimate on a substrate that has not been seemingly studied in the country.

When considering single taxa by groups, every member of Zygomycetes fructified within the first week of observation, and Pilaria anomala proved to be the most constant and dominant species of the group ( Wood \& Cooke, 1987), mainly in cold periods. In temperate zones, frequency of Piptocephalidaceae species (Mucoraceae, according to Benny, 2005) is common in rabbit dung, while Chaetocladiaceae species (Mucoraceae, according to Benny 2005) were much less frequent (Richardson,2005), a situation that was in agreement with our study. In the horse dung, Piontelli et al. (1981) found only similarities in the presence and frequency of $\boldsymbol{P}$. kleinii, Ch. brefeldii and $\boldsymbol{M}$. hiemalis, whereas Pilaria anomala was absent in that substrate.

Ascomycota species and mitosporic fungi were the biggest group of species in this substrate and we will focus our discussion mainly on the former by analyzing them as to the occurrence of gymnothecial, cleistothecial, perithecial and apothecial types.

The presence of Gymnoascus reessii gymnothecia (Eurotiomycetes, Onygenales, Gymnoascaceae), was detected late within 15 to 20 days, and coincides with the colonization in different kinds of faeces and types of soils rich in organic matter (together with other Gymnoascales) in many geographic regions (Domsch, et al , 1993; Currah, 1985, Delgado et al., 2001). Molecular analyses on Gymnoascaceae family correspond undoubtedly to a polyphiletic group included within the Onygenales (Sugiyama et al., 1999-2002; Guarro \& Cano, 2002) and taxonomic approaches designed at present are viewing Gymnoascus under a broader concept (Sole et al. 2002), tending to a synonymization of various taxa that had been considered as valid according to Currah' s approach (1985). This situation while not completely approved nowadays, needs a further sequence analysis on multiple genes data for every member of this family.

Among taxa forming cleistothecial ascomata we must take into account the presence of two species rarely found in the literature and which exhibit an even uncertain position within the Ascomycota, like Pleuroascus nicholsonii (¿Leotiomycetes, Pseudoeurotiaceae?) and Rhytidospora bispora (Sordariomycetes, Helotiales, ¿Ceratostomataceae?) Both taxa made their appearance within 10-15 day incubation of the substrate.

P.nicholsonii, is seemingly the most known species of the genus and which shows a cosmopolitan distribution, even though its findings are rarely found in the literature. It has been firstly isolated in England from Guinea pig dung (1901), in USA from rat woodrat (cf. Malloch \& Benny, 1973), from rabbit dung in Spain, ( Barrasa \& Moreno,1984) and in Australia from an undeterminate substrate (Bell, 2005). Our isolation does not differ morphologically from what has been described in the literature and it was characterized by having a pseudoparenquymatous peridium, blackish and brown ascoma together with hyaline spiralate appendages on their walls, 8 globose ascospores without germinative pore $(2,39-3,5 \mu \mathrm{m})$ with a $3.15 \mu \mathrm{m}$ average and with the presence of filaments which break down as enlarged to subglobose conidia, sometimes taking the shape of arthroconidia (Fig.2,9a). This species has presented different taxonomic histories with time but they have not been clearly defined yet, from its first inclusion in the Onygenaceae, Amauroascaceae or joint to the Arachnomyces species but they were not closely related to perithecial Eurotiales, but closely to the so-called discomycetes and loculoascomycetes, according to Suh \& Blackwell (1999). These authors change the concept of the Pseudoerotiaceae family and reduce the number of their members, while Gernandt et al. (2001), grouped the Pseudoeurotiaceae (in incertae sedis), next to the basal Helotiales, at a considerable distance from the Eurotiales, a situation that coincides with Gibas et al. (2002), who join P. nicholsonii to Leotiomycetes, and far from Arachnomyces species. Sogonov et al.(2005), comment also briefly in the Pseudoeurotiaceae the relationship between the closely related species of Connersia rilstonii with $\boldsymbol{P}$. nicholsonii (both with similar anamorphs).

Rhytidospra bispora, is one of the five species of the genus since its description by Jeng \& Cain (1977). Its habitat seems to be strictly coprophilous, but its rare detection in distant geographic zones does not allow to confirm this situation: it was isolated in Mexico from cow dung by Krug \& Jeng (1979), and it occurred likewise in Spain with the same type of dung by Valdoserra et al. (1991) and during this study with rabbit dung in the central zone of Chile. Our findings in a habitat dispersed by rodents and not by ruminants may indicate scarse selectivity in the case of a determinate kind of substrate. It showed no morphological differences from the two descriptions appearing in the literature. Superficial ascomata, 
cephalothecoid, non ostiolate globose (250-310 $\mu \mathrm{m}$ diam) yellowish to brown. Unitunicate asci,two spored, subglobose to elliptic 13- 17 x10-12 $\mu \mathrm{m}$; pitted ascospore, one celled, elipsoidal with a germ pore at each end.

The taxonomic position of this genus (Pezizomycotina, Sordariomycetes, Hypocreales, Ceratostomataceae) has not been clearly determined in the literature and Ericsson (2006), considers it as incertae sedis.

Valdoserra \& Guarro, (1994), described a new species of the genus (R. citriformis) in the coastal zone of northern Chile (Pisagua) in cow dung. Both species are quite similar, with two spored asci, yet they differ in size and shape of ascospores; ellipsoid with truncate ends in $\boldsymbol{R}$. bispora and limoniform in $\boldsymbol{R}$. citriformis.

Among genera that gave rise to the formation of perithecioid ascomata within 6 to 10 days, members of the Sordariales Order (Pezizomycotina, Sordariomycetes sensu stricto), a taxon recently analysed molecularly by Huhndorf \& Miller (2004), wherein only genera within Chaetomiaceae, Lasiosphaeriaceae and Sordariaceae families are retained among the redefined Sordariales. These three families are significant because of the high frequency of their members in our research.

The highest presence of species corresponded to Chaetomium (Chaetomiaceae), being dominant and frequent in most of the samples. Its species are isolated from a great variety of substrata: plant remains, queratine, feathers, seeds, dried spices, textiles, paper, cotton fibres, soil and indoor air (C. murorum, C.globosum, C. elatum), yet they seem to prefer sources containing cellulose; this is why they are frequently found in herbivore dung which are abundant in these carbonate nutrients as well as with a high nitrogen content. Although members of the taxon are not considered true coprophilous, but they do exhibit their competitive, defensive (mycotoxic) and metabolic abilities in this substrate.

C.globosum and other species of the genus produce sterigmatocystin,chaetoglobosin and chaetomin, among other toxins. (Sekita et al. 1981). Chaetomium bostrichodes seems to bear effective chemical defenses against fungusfeeding arthropods since sciarid larvae (Lycoriella mali) avoided their ascomata, but this was not the case with the other fungi coexisting in rabbit dung (Wicklow, 1988, in Wiklow, 1992). Other species can rarely be agent of opportunistic mycoses (De Hoog et al, 2000; Sigler \& Verweij, 2003).

Among the present species, it is worth to point out Chaetomium cuniculorum and $\boldsymbol{C h}$. murorum, the former being common in rabbit dung and the latter in diverse faeces (Bell, 1983, 2005), but we have found no references on $C$. cuniculorum in national research papers. In Chile, Piontelli et al. (1981), isolated frequently Ch. murorum and $\boldsymbol{C . e l a t u m}$ in equine dung, being these the only species matching with those from the rabbit dung in rather neighboring geographic zones, whereas Piontelli \& Grixiolli (1997) in the patagonic zone and Lazo (1979) in the central zone failed to isolate anyone member of this taxon in bovine and equine dung.

The literature on genus is large and it is condensed in the modern taxonomic treatment by von Arx, Guarro \& Figueras (1986), which we employ in our determinations, together with the always useful monography by Ames (1963) and the recent and beautiful illustrated guide by Bell (2005). Lee \& Hanlin (1999), study the phylogenetic relationships of Chaetomium and similar genera based on ribosomal DNA sequences, and Huhndorf \& Miller (2004) the molecular system of the Sordariales and especially the Lasiophaeriaceae family.

Two species of Podospora and two of Schizothecium were identified among the members of Lasiosphaeriaceae, S.tetrasporum showing overall dominance and constancy in time. Podospora is a widespread genus abundant in species (almost 80, Kirk et al, 2001) and which exhibits a great polymorphism , mainly in the structure of ascomata wall and ascospore appendages, having in mind that other taxa in the family bear similar characteristics to Podospora (Arnium, Cercophora, Strattonia, Tripterospora and Zopfiella). The genus is considered as one of the most frequent colonizers on diverse kinds of herbivore dung besides of having mostly coprophilous species, together with some of them present in plant material, seeds or soil, as it can be seen in various taxonomic papers in the literature(Mirza \& Cain, 1969; Lundqvist, 1972; Krug \& Khan, 1989; Bell \& Mahoney, 1995; Doveri, 1998, Stchigel et al, 2002; Bell, 2005, among others ).

Schizothecium, is a genus similar to Podospora and both of them have been treated in time like synonyms due to its lack of morphological characters that are not sufficient for its separation (Furuya \& Undagawa, 1972; Krug \& Khan, 1989; Bell \& Mahoney, 1995; Doveri, 1998, Lorenzo \& Havrylenko, 2001; Stchigel et al, 2002; Bell, 2005, among others). In its complicated history as regards nomenclature, Scizothecium revives thanks to Lundqvist's investigation (1972), who recognizes 17 species which are identified by the following characteristics: swollen agglutinated hairs on the ascomata, lack of filiform interascal paraphyses, early stage of septation of ascospore and persistent pedicel.

Most mycologists did not accept separation of these two genera (all those included above) as well as Bell \& Mahoney (1995) that in their revision of Podospora species with swollen agglutinated parithecial hairs, retained P.aloides, P.conica, $\boldsymbol{P}$. curvuloides, $\boldsymbol{P}$. dakotensis, P.miniglutinans, P. tetraspora and P. vesticola in the 
genus rather than in Schizothecium, as it is Lundqvist 's thought (1972).

However, Cai et al. (2005), in a phylogenetic study of multiple gene sequences, focused mainly in the relationships of Schizothecium and Podospora, and in a reevaluation of the taxonomic significance of morphological character of Schizothecium species having the general characteristics below: perithecia ornamented with swollen agglutinated hair or prominent protruding peridial cell, cylindrical to clavate asci usually without an apical ring, ascospore with a large brown cell, an small hyaline pedicel with or without gelatinous appendages and with phialidic anamorphs. They also observed that every strain under study is grouped in a strong supported monophyletic clade and concluded that they must have their own generic condition rather than being treated as congeneric to Podospora. However there is still a certain superposition of morphological characters, between these two genera in asci and ascospore what makes separation of both taxa difficult. (Bell \& Mahoney,1995). Notwithstanding, the actual phylogenic analysis indicate that ascomatal morphologies in Sordariales are more phylogenetically informative than ascospore characters, host or habitat association (Cai et al, 2005; Miller \& Huhndorf, 2005).

Schizothecium species can be considered mostly coprophilous (with mucilaginous appendages) yet some of them are non-coprophilous (soil, plants or other habitats) and they lack these appendages. Cai et al. (2005), based on the literature, added a listing in their paper and a nomenclature of 24 Schizothecium species bearing seven new combinations thus making valid Lundqvist 's investigation (1972) and suggested the need to complete his descriptions in future studies. Based on this lately contribution, we separated two species from Podospora and included them in Schizothecium (S. tetrasporum and S. miniglutinans). S. tetrasporum (三 Podospora tetraspora) was not isolated in Santiago and Linares (Lazo, 1979), nor in the patagonic zone (except for $\boldsymbol{S}$. miniglutinans that resulted dominant), although it was indeed present in equine dung in the V Region (Piontelli et al.1981). These two seemingly cosmopolitan species seem to adapt themselves quite well to diverse climates. Krug \& Khan (1989) state that $\boldsymbol{S}$. tetrasporum is a species feasible to be found in temperate zones and at a high altitude (Mirza \& Cain, 1969; Udagawa \& Kobayasi, 1979). Both Schizothecium species were also cited by Lorenzo \& Havrylenko (2001) for Argentina.

The two Podospora species (P. appendiculata and P. perpexens), have not been seemingly recorded in Chile. The former did not show any morphological difference from descriptions made by Mirza and Cain, 1969 and Lundqvist 1972, whereas in the latter, ascospores show their dark primary cell slightly longer than what it is described by these two authors, yet matching more closely to Bell 's findings ( 2005) in Australia (40-47 x 19-23 um)( $\mathrm{x}=$ $44,3 \times 21,6)$

Among Sordariaceae it is noteworthy the case of Sordaria, a quite coprophilous genus, yet some species are common too in the soil, seeds and vegetal detritus. Three species were frequent in both sampling periods; $\boldsymbol{S}$.

fimicola, S. humana and S. macrospora (sensu lato), a group of cosmopolitan species very much related one to the other and very common in dung of several herbivores (being rabbit dung one of them) under temperate zones (Lundqvist, 1972). S. fimcola did not show any significant morphometric difference from the literature (Moreau, 1953; Lundqvist, 1972; Guarro \& von Arx, 1987; Richardson \& Watling, 1997), whereas $\boldsymbol{S}$. humana, exhibited certain problems due to the different measures in ascospores, mainly in width since average measures exceeded standard figures, what left it far from S. fimicola and made it close to S. lappae (14-15 $\mu \mathrm{m}$ wide). S. humana, is described in a different genus for the fact of lacking unsheathed ascospores under the name of Asordaria humana (Guarro \& von Arx, 1987), but Asordaria is considered at present a synonym of Sordaria (Kirk et al. 2001). S. macrospora (sensu lato) showed ascospores with a 31.5x20-21um average having some intermediate measures with its neighboring species $\boldsymbol{S}$. superba $(26,4 \times 16,1 \mu \mathrm{m})$. This is why we prefer to keep all analized preparations under the first name..

S. macrospora and $\boldsymbol{S}$.fimicola were firstly isolated in horse dung (Piontelli et al.,1981) in the country, except for the patagonic zone(Piontelli \& Grixolli, 1997).

Another sordariaceae member having scarce presence was Neurospora calospora (=Gelasinospora calospora). Neurospora species have been found mostly in the moist tropics and subtropics as a primary colonizer of trees and shrubs killed by wildfires, yet they also appear in diverse soils and in the bark of many trees expanding significantly the known geographic range and habitats of the genus. Colonization occurred beneath the bark of diverse deciduous and conifer hosts. Ascospore morphology is the character for the distinction between the genera Neurospora and Gelasinospora, however it was not an accurate predictor of phylogenetic relationships as inferred from the sequence data analyzed (Dettman et al. 2001). García et al .(2004), based on ultrastructural and 28S rDNA sequence data, included the Gelasinospora species in Neurospora and described the new genus Pseudogelasinospora to match to Gelasinospora amorphoporcata. The similarity of both genera has been earlier recognized in the literature (Dowding, 1933; von Arx, 1982) together with another genus similar to Gelasinospora (a non-ostiolated 
counterpart) Anixiella Saito (Cain, 1961), which was refused by von Arx (1982). In our research work we do accept the inclusion of Gelasinospora in Neurospora, however in a recent paper, Cai et al (2006), in a phylogenetic investigation of Sordariaceae based in multiple gene sequences and morphology, agreed with previous studies that heterothallic Neurospora are monophyletic even though homothallic ones may have a multiple origin, considering there is insufficient evidence to place currently accepted Gelasinospora and Neurospora species within the same genus. It seems that history of both genera needs further study.

Sporormiaceae (Dothideomycetes, Pleosporales), characterized by fissitunicate asci, dark brown septate spores with germ slit, included several genera very common on dung and morphologically very similar to unclear circunscription (Arenal et al, 2004; Doveri, 2004; Nyberg, 2005). Recently Kruys et al. (2005), in a phylogenetic relationship of coprophilous Pleosporales showed that Delitschiaceae, Sporormiaceae, Zopfiaceae and Testudinaceae families form a monophyletic group, yet they must be retained as separate families since they fail to have a significant support. Sporormiella , Sporormia and Preussia are considered highly related genera and they are bound to be confused by their morphological features. Sporormiella Ell \& Everh., one of the 8 taxa included within the family by Barr (2000), is the most abundant in species and its members come mostly from a coprophilous habitat, yet some species (cf. S. intermedia) may occur on wood and soils (Ahmed \& Cain, 1972; Guarro et al, 1997; Barr, 2000). The genus included species with ostiolate ascomata, asci oblong to cylindrical, short stipitate or sessile, while Preussia its counterpart, presents ascomata non ostiolate (cleistothecioid), asci widely clavate and usually stipitate, it would include mainly species isolated from debris, wood and soil. Sporormiella, is generally considered a synonym of Preussia, a situation disapproved by some authors in the literature (Valdoserra \& Guarro, 1992; Guarro et al, 1997; Arenal et al, 2004).

In a phylogenetic study, Nyberg (2005) has proved that the presence or absence of the ostiole and a type of substrate is not a useful character for delimiting Preussia and Sporormiella (Guarro et al. ,1997; von Arx \& van der Aa, 1987), but the characters of the ascus may be important for the circunscription of some species of this genera, and suggested to continue treating these as separate because they do not form a monophiletic group. To this respect Bell (2005) has the same opinion. The greatest treatment of the genus belongs to Ahmed \& Cain (1972) and that of Furuya \& Udagawa(1972) is also useful. However separation of certain species becomes quite difficult because of the overlap between some of these, a situation occurring either in the coprophilous substratum as well as in the culture (Arenal et al, 2004; Bell, 2005; Nyberg, 2005).

Two members of the genus Sporormiella ( $\boldsymbol{S}$. intermedia and $\boldsymbol{S}$. teretispora, were isolated with a high frequency and constancy in both periods, the latter being the most constant as well as dominant. Determination of the preparations designed for $\boldsymbol{S}$. teretispora revealed stable measures on their asci (182-210 x 30-35 $\mu \mathrm{m})$ and ascospores (60-69 x 11,5-13 $\mu \mathrm{m})$ what induced us to include it in this species, following Ahmed \& Cain (1972) and Khan \& Cain (1979) monographie, whereas $S$. intermedia was identified because its ascospores were always lesser than 60um long (48-55 x 9,5-10,5 $\mu \mathrm{m})$. Considering the feasible changeability of these two species, it is difficult to ascertain absolutely and only through morphology that they are the result of variants from a single ( $\boldsymbol{S}$. intermedia), since there is a coincidence in their structures such as the germinative furrow generally obliquous, the biseriate arrangement of ascospores in the asci, and the shape and size of asci and paraphyses. Bell (1983) had some difficulties in placing his collection within these two species, because of a possible overlap between them, and in a recent work (Bell, 2005), broadly defined S.intermedia (sensu lato) with a larger ascospore range. (50-) $55-77$ x (9-) 10-13 (-14).

S. intermedia is one of the most well-known species in many herbivore dung (Ahmed \& Cain, 1972; Ellis \& Ellis, 1988; Valdoserra \& Guarro, 1990; Bell, 1983, 2005) and its distribution along several regions of Chile has firstly been confirmed by Lazo (1979) and Piontelli et al.(1997), whose measurements on ascospores (48,5- 54,4 $\mathrm{x} 8,8-11,9 \mu \mathrm{m})$, do fit the original description. Members of Pleosporales, mainly those of the Sporormiaceae family play a significant role in the production of secondary metabolites having diverse functions, such as fitotoxic, antifungal, antibactericide and cholesterol biosynthesis inhibitors (S. minima). Various antifungal compounds (Terezines A-D) and the fungal metabolite Hialophyrone (Wang et al,1995; Huang \& Kaneko, 1996; Hatory et al., 2004). have been isolated from S.teretispora.

Another family within Pleosporales which was rarely represented included only one member of Phaeotrichaceae as Trichodelitschia munkii, with perithecia neck ornamented with dark non septate bristles, asci bitunicate-fissitunicate with apical rings and ascospore uniseriate, dark, bicellular with prominent polar germ pore (see Lundqvist, 1964; Luck-Allen 1970; Barr 2000).

Nyberg (2005), in a phylogenetic relationship of coprophilous Pleosporales families grouped with high support Trichodelitschia with Phaeotricum (Lundqvist, 1964; Barr 2000).There is, as it seems no isolation records 
of this species in Chile.

Within Pezizomycetes, the Pezizales Order is an interesting group of fungi bearing diverse habitat, appearence, nutritional strategies and ecological behavior (saprophytic, parasitic and ectomycorrhizal), which was represented by three families (Pezizaceae, Ascobolaceae and Ascodesmiaceae ). Considering its frequency in the two climatic periods, a single member of Pezizaceae is noteworthy as Iodophanus carneus, one of the most common discomycetes found in different types of dung with a worldwide distribution and having Oedocephalum anamorph in some species. (Kimbrough et al. 1969, Kimbrough, 1982). The genus Iodophanus is a segregate of the coprophilous genus Ascophanus and is characterized by the pinkish color of its gregarious apothecia, presence of diffuse amyloidy of asci, hialine elipsoidal ascospores and carotenoid pigments in paraphyses and excipular cells. Dominance of this coprophilous species has been earlier recorded in diverse chilean geographic zones in other coprophilous substrate (Lazo, 1979; Piontelli et al.,1981; Piontelli \& Grixolli, 1997).

In a study of multiple nuclear genes, Pezizaceae is supported as a monophyletic group (Hansen et al, (2005), a situation confirmed also by De Hoog et al. (2005) based on one gene only, however this family seems not to be closely related with other families thus it would be necessary to restrict possibly Pezizaceae as the unique taxon within Pezizales, as well as to carry out further future confirmatory studies which allow at the same time to apply new ordinal names for the other families. It seems advisable to maintain still the current taxonomic situation (Kirk et al, 2001; Eriksson, 2006) considering families of the order under the concept of Pezizales sensu lato.

The Ascobolaceae family(Pezizomycetes, Pezizales) was represented by members of two genera only, Ascobolus and Saccobolus. The unique species of Ascobolus had a sporadic occurrence in the two periods and it was not possible to confirm it at a species level as by the available information. Based on the morphology described under results it can be included in the Sphaeridiobolus section because of its close similarities to the A.brassicae, species yet having much bigger ascospores (26-30 $\mu \mathrm{m}$ diam). Ascobolus species having spherical or subspherical ascospores and described by van Brumelen (1967) are few in number: A. brassicae, $A$. crosslandii, A subglobosusus, A.reticulatus, however all of them are under dimension ranks and exhibit a different epispore (Fig. 1,5). A revision of some of the lately literature (van Brumelen,1980; Dissing, 1989; Wang \& van Brumelen 1997; Gamundi et al, 2004; Dokmetzian, et al, 2004, 2005), failed to find any similarity to our record which it will be examined later on.

It is worth while to state that based on recent studies related to the mechanism of forcible ascospore discharge in A. immersusus, 8 ascospores can be discharged as a single mucilage-embebbed projectile with a $0,3 \mathrm{Mpa}$ or 3 atm. pressure, with a glycerol as a mayor osmolyte (Fischer, et al, 2004).

The other most well-known member of the Ascobolaceae family was Saccobolus with 3 species, most of them showing a low frequency, except for $\boldsymbol{S}$. taxterii. The genus is cosmopolitan and widely dispersed in different coprophilous substrate. The most useful monography keeps still being that of van Brumelen (1967), however his number of species has increased at present in the literature (van Brumelen, 1976; Aas, 1978; Dissing, 1989; Wang \& van Brumelen 1997). The identification of species (26 according to Kirk et al, 2001) conveys some difficulties in the sense that it is based on various factors which are not sometimes easy to evaluate because they are very alike: the ascomata color with aging process, the color of paraphyses, the arrangement of ascospore in the ascus (6 group), all of them linked together in a jellied mass, change in color of the latter with age (generally reddish wine) as well as and the shape and ornamentation of those. This situation observed in various papers about the species of the genus (for example Bell, 1983, 2005), could be seen in the most common species that we identified as $\boldsymbol{S}$. taxterii, a species related to $\boldsymbol{S}$. verrucisporus, and $S$. versicolor (being the latter a very changeable species). We discarded the former either for its coarsely punctate ascospores and fine anastomosing fissure, and the latter for its more o less smooth and fissured ascospores.

The Ascodesmidaceae was rarely represented and Lasiobolus intermedius was the only species of the genus found. This taxa (operculate discomycetes), with hialine thick-walled bristles on sessile minute apothecia had been placed previously in the family Theleboleceae (Kimbrough \& Korf , 1967). Lasiobolus is another genus which exhibits high changeability in bristle morphology and ascospore arrangement (Bezerra \& Kimbrough, 1975); according to van Brumelen (1998), the asci of Lasiobolus and Coprotus agree with the earlier defined Octospora type. Phylogenetically Lasiobolus and Ascodesmis, which have been suggested as closely related to Orbicula and Lasiobolidium, are a sister lineage to the Pseudombrophila (Landvik et al.,1998; Hansen et al., 2005).

In our isolations, the ellipsoidal, hyaline ascospores (many with Bary bubble) measured 17,5 -19,5 $\mathrm{x} 10,50-12,50 \mu \mathrm{m}$ (with a 18,5 x 11,5 $\mu \mathrm{m}$ average), dimensions that do agree with the ranks of species $\boldsymbol{L}$. cuniculi, $\boldsymbol{L}$. intermedius y $\mathbf{L}$. ciliatus, however considering other isolations collected from other substrate in the chilean central zone and the Patagonia (Piontelli \& Grixolli, 1997), where practically the same dimensions resulted, we 

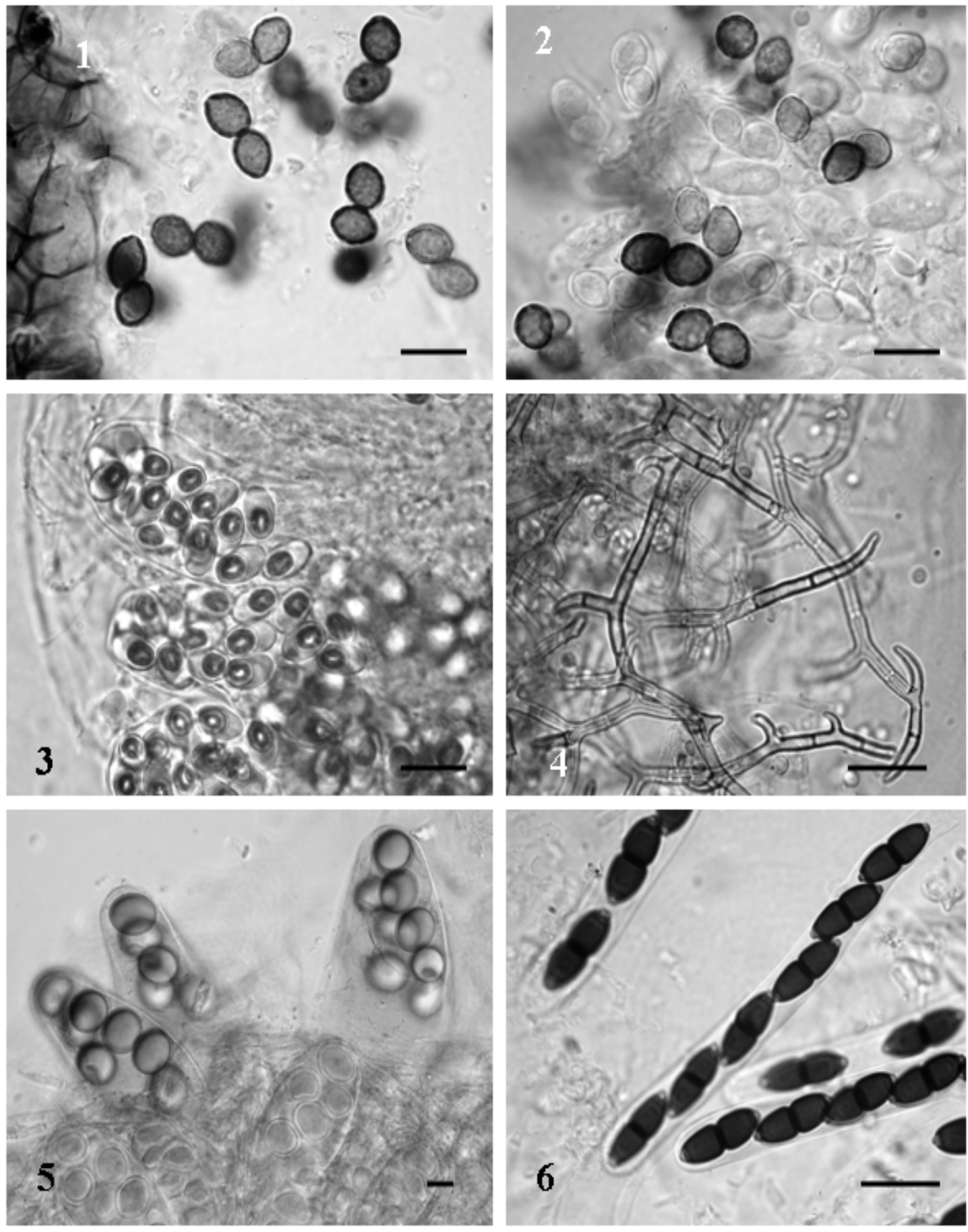

Figure 1.- 1,1-1,2. Rhytidospora bispora, 1,1. Ascoma peridium and ascospores. 1-2. Bispored asci. 1,3. Coprotus sexdecimsporus, asci and ascospores. 1,4. Gymnoascus reesii, peridial gymnothecial hyphae with hooked appendages and ascospore. 1,5. Ascobolus sp. Asci with round ascospores. 1,6.Trichodelitschia munkii, bitunicate asci an ascospores with 2 polar germ pores $(\mathrm{Bar}=20 \mu \mathrm{m})$.

classified the species as, $\boldsymbol{L}$. intermedius (?). This decision based mainly on Bezerra and Kimbrouugh (1975), nomenclature includes it among those species having ascospores lower than $20 \mu \mathrm{m}$ (in our case they kept always near to their maximum length limit). Moreover another morphological features were taken into account which proved to be seemingly quite changeable such as the arrangement of ascospores in the ascus (uniseriate or biseriate), length and width of asci (100-200 x 18-25 $\mu \mathrm{m})$, the non septate pointed setae, slightly ventricose at their bases (120-270 x 9-15 $\mu \mathrm{m}$ ), the filiform paraphyses and the cells of ectal excipulum. We commented with other authors 

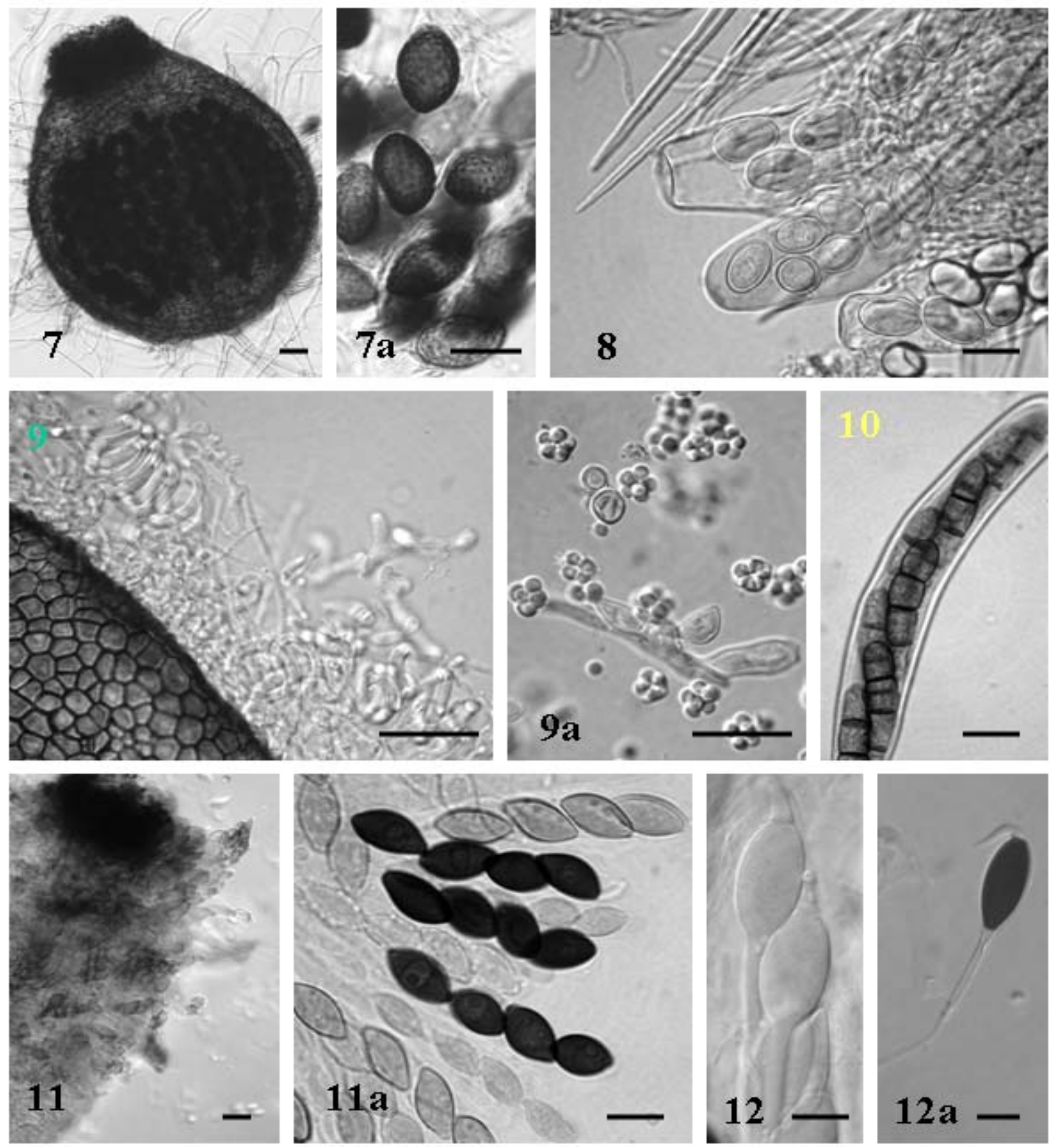

Figure 2.- 2,7. Neurospora calospora, ostiolate perithecia. 2,7a. Apiculate ascospores with circular and inwardly pits. 2,8. Lasiobolus intermedius, ascus, ascopores and setae. 2,9. Pleuroascus nicholsonii, peridium cell of cleistothecium with coiled appendages. 2,9a. Asci, ascospores and fragmented filaments (conidia). 2,10. Sporormiella teretispora, cilindrical asci and biseriate ascospore four celled. 2,11-2,11a. Schizothecium tetrasporum, perithecia with inflate and agglutinated hairs; asci and ascospores. 2,12-2,12a. Podospora perplexans, young and mature ascospores with apical caudae, pedicel and basal cauda $(\mathrm{Bar}=20 \mu \mathrm{m})$.

how difficult it was to separate $\boldsymbol{L}$. intermedius from $\boldsymbol{L}$. ciliatus and $\mathbf{L}$ cuniculi (Bezerra \& Kimbrough, 1975; Wang, 1995; Richardson \& Watling, 1997; Spooner \& Butterfill, 1999; Bell 2005, among others) and the fact that morphometry of their major structures is varied among the different authors. Bell (2005), preferred to enclose these 3 similar members under the sole name of $\boldsymbol{L}$. ciliatus. A decision that we could have defended quite logically, 

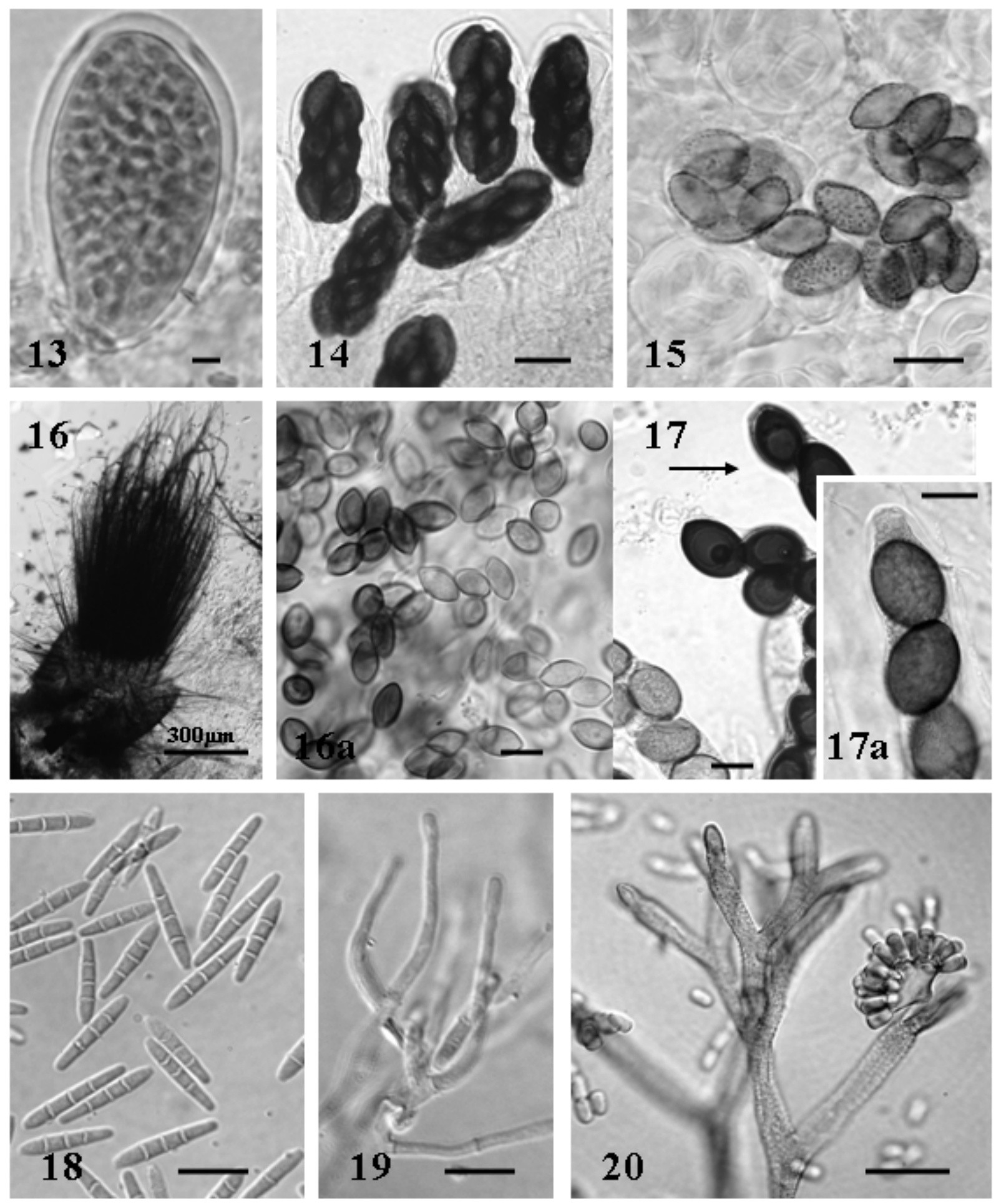

Figure 3.- 3,13. Thelebolus stercoreus, mature ascus and ascospores. 3,14. Saccobolus thaxteri, group of mature spore cluster in asci. 3,15. Saccobolus globuliferellum, asci and spore cluster loosely united. 3,16-3,16a. Chaetomium cuniculorum, details of perithecium hairs and mature ascospores. 3,17-3,17a. Sordaria humana, mature ascus with 7 ascospore (arrow indicate a genetic fusion of 2 acospores); immature ascus tip with apical ring. 3,18-3,19. Fusariella hughesii, cylindrical to narrowly ellipsoid conidia generally 3 septate, and monophialidic conidiogenous cell. 3,20. Piptocephalis freseniana, merosporangia, mitospores and inverted conical head cell (Bar $=10 \mu \mathrm{m})$. 
however the small number of ascomata found (only five) together with the information collected from the morphological features analyzed induced us to take this decision, that might be considered as well under the broader term of L.ciliatus group or sensu lato.

Lasiobolus is one of the most frequent discomycetes ocurring in ruminant dung (Richardson, 1972), yet a special approach intended for a particular substratum is still missing (Caretta et al, 1998). L. ciliatus, specially and $\boldsymbol{L}$. intermedius, its possible parental species, have been isolated from temperate through cold zones, such as southern soils of the argentinian Patagonia and chilean Tierra del Fuego (Lazo, 1979; Piontelli et al, 1981; Valdoserra \& Guarro, 1992; Piontelli \& Grixolli, 1997; Gamundi et al, 2004).

The two last discomycetes bearing a scarce representation in the substratum were: Coprotus sexdecimsporus and Thelebolus stercoreus, species that are considered by Eriksson (2006) within the Leotiomycetes (Thelebolales, Thelebolaceae), or may be Coprotus within Pyronemataceae, Pezizales (Kirk et al., 2001). It is significant to remark according to Hambleton \& Sigler (2005), that two members of the Myxotrichaceae family formed a clade with 2 members of the Thelebolaceae (Ascozonus woolhopensis y T. stercoreus ) with a high statistical support. Based on Currah's investigation (1994), it is suggested that the Myxotrichaceae might represent a distinct evolutionary line from the members of Onygenales (inoperculate discomycetes) and this distant relationship has been confirmed by Sugiyama et al, 1999; Sugiyama \& Mikawa, 2001; Hambleton et al.,2005: Jiang \& Yao, 2005; Wang et al,. 2006, and others, who relate the taxon with Leotiomycetes (Leotiales and Erysiphales).

Coprotus, is an essentially coprophilous genus that has a late occurrence in this substratum (20-25 days), with light colored small and sessile apothecia free of setae, eigth to multispored non amyloid asci with hyaline, smooth and ellipsoid ascospores and a conspicuous and constant du Bary bubble, were the major features of the genus. The only species present was $\boldsymbol{C}$. sexdecimsporus, the morphological characteristics of which agreed with the description of the type species of the genus according to Kimbrough et al, (1972). These authors supplied the keys for northamerican species, determined their taxonomic distribution suitable at that age, together with their similarities to other related or alike genera such as: Ascophanus, Rhypariobolus, Ascozonus and Coprobia among other. However their operculate asci as well as du Bary bubble in the ascospore allow their differentiation from these. Other authors added more species to the genus or else described the normal ones in different countries (Jeng \& Krug, 1977; Aas, 1983; Gené et al., 1993; Wang, 1999; Doveri et al., 2000; Dokmetzian et al., 2005). C. sexdecimsporus, seems to have no preference for a particular type of dung (Kimbrough et al, 1972) and its presence had been detected earlier in Chile in horse and cow dung (Lazo, 1979; Piontelli et al. 1981), but this was also the case also in several places in Argentina, Tierra del Fuego and Antarctic zone (Gamundi et al., 2004; Dokmetzian et al., 2005).

Thelebolus is a morfologically simple and small cleistohymenial ascomycete with asci containing 8 to over 2000 ascospores. Its echology continues being still uncertain for various species and most of them are psychrophilic and frequently isolated from the Antarctica (Montemartini et al., 1993; Azmy \& Seppelt, 1998; De hoog et al., 2005). De Hoog et al.(2005), in a phylogenetic and ecological study of Thelebolus in Antarctic zones agree with the idea of classifying this genus and other related such as Ascozonus and Caccobius (among others) in a separate Thelebolales order near the Leotiales in a single family Theleboleceae (Landvik et al., 1998; Kirk et al., 2001), at a certain distance from other discomycetes members of the Pezizales. Van Breumelen (1998), reconsiders the relationship within the Thelebolales based on ascus ultrastructure, finding at least 3 different types of asci in Thelebolus species and maintain the earlier definition of Octospora type intended for Lasiobolus and Coprotus asci

T. stercoreus, exhibiting 2 to 4 asci together with 256 spores (we observed 92 spores in a single plane), is one of the most changeable species within the genus and capable of bearing an hymenium with a variable number of asci from 1 to 40 as regards the quantity of ascospores present ( $>$ number of ascospores < number of asci), a situation which has meant problems for the definition of species in the genus, since the research work performed by Kimbroug \& Korf (1967). De Hoog et al. (2005) accept nowadays only 4 species in the genus, 2 of them new for the Antarctica while $\boldsymbol{T}$. stercoreus includes the well-known T. caninus, T. crustaceus, T. psychrophilous species as synonyms, among others. Its cosmopolitan distribution occurs essentially in different coprophilous substrate collected from mammals and poultry in cold and temperate regions yet it has never been found in the Antarctica (De Hoog et al., 2005; Gamundi et al., 2004). In Chile, Thelebolus stercoreus has been isolated from cattle and horse dung in temperate and cold zones (Piontelli et al., 1981; Piontelli \& Grixolli, 1997).

We have focused the discussion based on our second objective and we will just add a brief comment on some representative mitosporic fungi related to Ascomycota, generally considered only as a small part within the dung inhabitants, in a substratum that can become a box of surprises as regards change in abundance 
and diversity of this taxa (Seifert et al. 1983), nearly to $40 \%$ and which matches not only with the kind of coprophilous substratum and other physiological or environmental variants, but also largely with the composition of the vegetation (grasses and leaf litter), the soil mycota and the kind of antifungal antibiosis in the coproma community, a situation that we proved as an example in the case of Stilbella erythrocephala, which when growing, refused the presence of any neighboring mycobiota (Leher et al., 2006). Among the records of the most well known fungal propagules in the litter, Alternaria, Cladosporium and Aspergillus had a poor representation, while some taxa of rare occurrence such as: Chaetomella acutiseta var. nigra, Clonostachys rosea f. rosea, Fusariella hughesii, Harzia verrucosa,
Ochroconis tshawytschae, among others, could be observed in herbivore dung (Table 1), taking no account of those that our observation failed to detect in the low number of samples collected (Richardson, 2001 recommended to collect 40-50).

From the clinical point of view, diversity of fungal species detected in this coprophilous substratum belonging to the external habitat of a public hospital, is not seemingly a significant source of dispersion of potentially pathogenous fungi for man.

This paper presents a limited range of coprophilous fungi in special habitats affected by anthropogenic activities and these results are a source of a rich and attractive microfungal community in a selective and beautiful microcosms of biodiversity.

\section{REFERENCES}

Aas,O. (1983). The genus Coprotus (Pezizales) in Norway. Nordic J. Bot. 3:253-259

Ahmed, S.I. \& Cain, R.F.(1972). Revision of the genera Sporormia and Sporormiella. Can. J, Bot. 50:419-477

Ames, L.M. (1963). A monograph of the Chaetomiaceae. The unites States Army research and developpmental series.

Angel, K. \& Wickow, D.T. (1983). Coprophilous fungal community in semiarid to mesic grassland. Can. J. Bot. 61:594-602

Arenal, F.; Platas, G.\& Pelaez, F. (2004). Variability of spore leng in some species of genus Preussia (Sporormiella). Mycotaxon 89:137-151

Arx, J.A.von. (1982). A key to the species of Gelasinospora. Persoonia 11:443-449

Arx, J.A. von. \& Aa, H.A. van der. (1987).Spororminula tenerife gen. et sp. nov. Trans. Br. mycol. Soc 89:117-120

Arx, J.A.von.; Guarro, J. \& Figueras, M.J. (1986). The Ascomycete genus Chaetomium. Nova Hedwigia 84:1-161

Azmi, O.R. \& Seppelt, R.D. (1998) The broad-scale distribution of microfungi in the Windmill Island region, continental Antarctica. Polar biology 19:92-10

Barr, M.E. (2000). Notes on coprophilous bitunicate ascomycetes. Mycotaxon 76:105-1012

Barrasa, J.M. \& Moreno, C. (1984). Hongos copróilos de España III. Anales Jard. Bot. Madrid . 41:3-17

Bell, A. (1983). Dung Fungi. An Illustrated Guide to Coprophilous Fungi in New Zealand. Victoria University Press, Private Bag Wellington.

Bell, A. (2005). An illustrated guide to the coprophilous Ascomycetes of Australia. CBS, Utrecht, The Netherland

Bell, A. \& Mahoney, D.P. (1995). Coprophilous fungi i New
Zealand. I. Podospora species with swollen agglutinated perithecial hairs. Mycologia 87:375-396

Benny, G.L. (2005) Zygomycetes. http:/www.zygomycetes.org/

Bezerra, J.L. \& Kimbrough, J.W. (1975). The genus Lasiobolus (Pezizales,Ascomycetes).Can. J. Bot.53:1206-1229

Cai, L,; Jeewon, R \& Hyde, K. (2005). Phylogenetic evaluation and taxonomic revision of Schizothecium based on ribosomal FNA and protein code genes. Fungal diversity 19:1-21

Cai, L,; Jeewon, R. \& Hyde, K. (2006). Phylogenetic investigations of Sordariaceae based eo multiple gene sequence and morphology, Mycol. Res. 110:137-150

Cain, R.F.(1961). Anixiella and Diplogelasinospora, two genera with clestothecia and pitted ascospores. Can. J. Bot. 39:16671677

Caretta, G.; Mangiarotti, A.M. \& Piontelli, E. (1994). Coprophilous fungi on horse, goat and sheep dung from Lombardia (Italy). Micologia Italiana 23:11-20

Caretta, G. \& Piontelli, E. (1996).Coprophilous fungi from confined deers in Pavia (Lombardia, Italy). Boletín Micológico $11.41-50$

Caretta,G.; Piontelli.E.; Picco.A.M. \& Del Frate, G. (1999). Some Filamentous Fungi on Grassland Vegetation from Kenya. Mycopathologia 145:155-169

Caretta, G.; Piontelli, E.; Savino, E. \& Bulgheroni, A. (1998). Some coprophilous fungi from Kenya. Mycopathologia 145:125134

Christensen, M. (1981). Species diversity and dominance in fungal communities. In The fungal community: Its organization and role in the ecosystem (Wicklow, D.T. \& Carrol, G.C. eds.), Marcel Dekker, N.York. pp. 201-232

Currah, R.S.(1985). Taxonomy of the Onygenales: Arthrodermataceae, Gymnoascáceae, Myxotrichaceae and Onygenaceae. 
Mycoraxon24:1-216

Currah, R.S. (1994). Peridial morphology and evolution in the prototunicate ascomycetes. In: Ascomycete ssystematics: problems and perpective in the nineties (Hawksworth, D.L. ed.), Plenum press, N.York pp 281-293

De Hoog, G.S.; Guarro, J.; Gené, J \& Figueras, M.J. (2000). Atlas of clinical fungi. 2nd ed. CBS, Nederland, Univ. Rovira i Virgili, Reus, Spain.

Delgado, A.A..; Piñeiro, C.A. \& Urdaneta, G.L. (2001). Hongos coprófilos del estado de Zulia, Venezuela. Clases: Plectomycetes,y Discomycetes.División Ascomycota. Rev. Científica FCV-Luz 11:297-305

Dettman, J.R.;Harbisnski, F.M. \& Taylor, J. (2001), Ascospore morphology is a poor predictor of the phylogenetic relationships of Neurospora and Gelasinospora. Fungal Genetic and Biology 34:49-61

Dissing, H. (1989). four new coprophilous species of Ascobolus and Saccobolus from Greenland (Pezizales). Opera Botanica 100: 43-50

Dokmetzian, D.A.; Gimenez, M.C.; Cinto, I.E. \& Renalli, M.E. (2004). Estudio sistemático y Biológico de las Ascoboláceae de Argentina XIX. Dos nuevas especies de Ascobolus (Ascomycota). Hickenia 3(49):205-211

Dokmetzian, D.A.;Ramos, A.M.;Cinto, I.E.; Suárez, M.E.; Renalli, M.E. (2004). Seis especies del género Coprotus (Pyronemataceae) de Argentina estudiadas en cultivo. Hickenia 3 (57):243-252

Dokmetzian.; Renalli, M.E. \& Saidman, B.O. (2005). Isozyme analysisi of twelve species of the genus Ascobolus. Mycotaxon 92:295-309

Domsch, K.H.; Gams, W. \& Anderson, T-H. (1993). Compendium of soil fungi. Vol.I (reprint). IHW-Verlag Eching.

Doveri, F.; Cacialli, G. \& Caroti, V. (1998).Indagine preliminare siu funghi fimicoli dell'isola della Cona con aggiornamento sul genere Podospora in Italia. Contributo allo studio dei funghi fimicoli XXIII. Pagine di Micologia 9:25-69

Doveri, F.; Cacialli, G. \& Caroti, V. (2000). Guide pour l'identification des Pezizales fimicoles d'Italie. Contribution á l'etude des champignon fimicole XXXII. Documents Mycologiques. 117-118:3-97

Doveri, F. (2004). Fungi fimicoli Italici: A guide to the recognition of basidiomycetes and ascomycetes living in fecal material. Ass. Micol. Bresadola, Trento

Dowding, E.S.(1933). Gelasinospora a new genus of Pyrenomycetes wiyh pitted ascospores. Can. J.Res. Sect. C 9:294305

Ellis, M.B.(1971). Dematiaceous Hyphomycetes. Commonw, Mycol. Inst. Kew.

Ellis, M.B.(1976).More Dematiaceous Hyphomycetes. Commonw. Mycol. Inst. Kew.

Ellis, M. B. \& Ellis, J.P. (1988). Microfungi on Miscellaneous
Substrates. Croom Helm, London and Sidney.

Eriksson,O.E.(2006). Outline of Ascomycota. Myconet 12.1-82

Fischer, M.; Cox, J.; Davis, D.J.; Wagner, A.; Taylor, R.; Huerta, A.J.; Money, N.P. (2004). New information on the mechanism of forcible ascospore discharge from Ascobolus immersus. Fungal Genet. Biol. 41.:698-707

Furuya,K. \& Udagawa, S-I. (1972). Coprophilous Pyrenomycetes from Japan I. J.Gen. Microbiol. 18:433-454

Gamundi, J.I.; Minter, D.W.; Romero, I., A; Barrera; V. A.; Gaiotti, A.L.; Messuti, M.I.; Stecconi, M. (2004). Checklist of the discomycetes (Fungi) od Patagonia, Tierra del Fuego and Adjacent antartic areas. Darwiniana 42:63-164

García, D.; Stchigel, A.M.; Cano, J.; Guarro, J.; Hawksworth, D.L. (2004). A synopsis of re-circumscription of Neurospora (Syn. Gelasinospora) Based on ultrastructural and 28S rDNA sequences data. Mycol. Res. 108: 1119-1142

Gené, J.; ElShafie, A.E. \& Guiarro, J.(1993). Two new coprophilous Pezizales from the Sultanate of Oman. Mycotaxon 46:275-284

Gernandt,D.S.; Platt,J.L.;Stone, J.K.; Spatafora, J.W.; Holst-Jensen, A.;Hamelin, R.C.; Kohn, L.M. (2001). Phylogenetics of Helotiales and Rhytismatales based on partial small subunit nuclear ribosomal DNA sequences.Mycologia: 93:915-933.

Gibas, C.F.; Sigler, L.; Summerbell.\& Currah, R.S. (2002).Phylogeny of the genus Arachnomyces and its anamorphs and the establishment of Aragnomycetales, a new Eurotiomycete order in the Ascomycota. Stud. Mycol. 47:131-139

Guarro, J.; Abdullah, S.K.; Gene, J.\& Al-Saadoon, A.H. (1997). A new species of Preussia from submerged plant debris. Mycol Res. 101:305-308

Guarro, J. \& Cano, J. (2002). Phylogeny of Onygenalean fungi of medical interest. Stud. In Mycol. 47:1-4

Hambleton, S. \& Sigler, L. (2005). Meliniomyces, a new anamorph genus for root-associated fungi with phylogenetic affinities to Rhizoscyphus ericae (=Hymenoscyphus ericae) Leotiomycetes. Studies in Mycology 53: 1-27.

Hambleton, S.; Nickerson, N.L. \& Seifert, K.A. (2005). Leohumicola, a new genus of heat-resistant hyphomycetes. Studies in Mycology 53: 29-52.

Hansen, K.; Lobuglio, K.f. \& Pfister, D.H. (2005).Evolutionary relaqtionships of the cup-fungus genus Peziza and Pezizaceae inferred from multiple nuclear genes: RPB2, beta tubulin, and LSU rDNA. Mol. Phylogenet. Evol. 36:1-23

Harper, J.E. \& Webster, J.(1964). An experimental análisis of the coprophilous fungal succession.Trans. Br. myco. Soc. 47:511530

Hatory, H,: Shibata, T.; Tsurumi, Y.;Nakanishi. T.; Katsuoka, M.et al. (2004). FR171456, a novel Cholesterol synthesis inhibitors produced by Sporormiella minima $N^{\circ} 15604$. J.Antibit. 57:253-259

Hoog, G.S. de.; Göttlich, E.; Platas, G..; Genilloud, Leotta 
G. \& Brummelen, J. van. (2005). Evolution taxonomy and ecology of the genus Thelebolus in Antarctica. - Studies in Mycology 51: 33-76.

Huang, L.H. \& Taneko, T. (1996). Pyrenomycetes and Loculoascomycetes as source of secondary metabolites. J. Indust. Microbio. Biotechn.17:402-416

Huhndorf, S.M, \& Miller, A.N. (2004). Molecular systematic of the Sordariales: the order and the family Lasiophaeriaceae redefined. Mycologia 96:368-387

Jeng, R.S. \& Krug, J.C. (1977). New species and new records of coprophilous Pezizales from Argentina and Venezuela. Can. J. Bot. 55:2987-3000

Jiang, Y \& Yao,Y-J. (2005). ITS sequences analysis and ascomatal development of Pseudogymnoascus roseus. Mycotaxon 94:55-73

Khan, R.S. \& Cain, R.F. (1979). The genera Sporormiella and Sporormia in East Africa. Can. J. Bot. 57:1174-1186

Kimbrough, J. W. \& Korf, R.P. (1967). A synopsisof the genera and species of the tribe Thrlebolaceae(Pseudoascobolaceae) Am. J. Bot 54:9-23

Kimbrough, J.W.; Luck-Allen, e.R. \& Cain, R.F. (1969). Iodophanus, the Pezizaceae segregate of Ascophanus (Pezizales). Amer. J. Bot. 56:1187-1202

Kimbrough, J. W. (1982). The Discomycetes. In an Encyclopedia of Taxonomy and Classification of Living Organisms. McGrawHill Book Company, N.Y. 231-242 pp.

Krug, J.C. \& Khan, R.S. (1989). New records and new species of Podospora from East Africa. Can. J. Bot. 67:1174-1182

Landvik, S.; Kristiansen, R. \& Schumacher,T. (1998). Phylogenetic andd structural studies in the Thelebolaceae (Ascomycota). Mycoscience 39:49-56

Larsen, K. (1971). Danish endocoprophilous fungi, and their sequence of occurrence. Bot. Tidsskrift 66:1-32

Lazo; W. (1979) Hongos coprófilos de Chile. Archivos de Biol. y Med. Exper. 12:637 (Resumen).

Lee,S. \& Hanlin, R.T. (1999). Phylogenetic relationships of Chaetomium and similar genera based on ribosomal DNA sequences. Mycologia 91:434-442

Leher, N-A.;Meffert, A.;Antelo, L.;Stemer, O.;Anke, H.; Weber, R.W.S. (2006).Antiamoebins, myrocin B and the basis of antifungal antibiosis in the coprophilous fungus Stilbella erythrocephala (Syn, S.fimetaria). FEMS Microbiol. Ecol. 55:105-112

Lorenzo.L.E. \& Havrylenkom M. (2001). The genera Arnium and Podospora from Argentina. Mycologia 93:1221-1230

Luck-Allen, E.R. (1970). A new Species of Trichodelitschia. Nova Hedwigia 19:305-309

Lundqvist,N.(1964). The genus Trichodelitschia in Sweden. Bot. Tidskr. 58:267-272

Lundqvist,N.(1972) Nordic Sordariaceae s. lat. Symbolae Botanicae Upsalienses 20:1-314
Malloch, D. \& Benny, G.L. (1973). California Ascomycetes: four new species and a new record. Mycologia 65:648-660

Miller, A.N. \& Huhndorf, S.M. (2005). Multi-gene phylogenies indicate ascomal wall morphology is a better predictor of phylogenetic relationships than ascospore morphology in the Sordariales (Ascomycota). Molecular Phylogenetics and Evolution, 35:60-75

Mirza, J.H. \& Cain,R.f. (1969). Revision of the genus Podospora. Can. J. Bot. 47:1999-2048

Montematini, A. Caretta, G. \& Del Frate, G.. (1993). Notes on Thelebolus microsporus isoalted in Antarctica. Mycotaxon 48:343358

Moreau, C.(1953). Les genres Sordaria et Pleurage. IN: Encycl. Mycol. 25:1-330

Nyberg, A.K. (2005). Phylogenetic relationships and species richness of coprophilous Ascomycetes. Umeà Univ, Dep.Ecology and Environ.Sci., Umeà, Sweden. Doctoral dissertation. pp. 1-26

Piontelli, E.;Toro SantaMaria, M.A. \& Caretta, G. (1981). Coprophilous fungi of the horse. Mycopathologia 74:89-105

Piontelli, E. \& Grixolli, A. (1997). Microhongos de la Patagonia Chilena: Algunos Ascomycetes coprófilos. Boletín. Micológico 12:13-24

Richardson, M.J. (1972). Coprophilous Ascomycetes on different dung types. Trans. Br. mycol. Soc. 59:37-48

Richardson, M.J. \& Watling, R. (1997). Keys to fungy on dung. British Mycological Society.

Richardson, M.J. (2001). Diversity and occurrence of coprophilous fungi. Mycol. Res.105:387-402

Richardson, M.J. (2005). The occurrence and distribution of Piptocephalis, Syncephalis and Chaetocladium species on dung.Mycol Res.109:1425-1428

Seifert, K.; Kendrick, B. \& Murase, G . (1983). A key to Hyphomycetes on dung. University of Waterloo Biology Series No. 27. Ontario, Canada.

Sekita S, Yoshihira K, Natori S, Udagawa S, Muroi T, Sugiyama Y, Kurata H, Umeda, M. (1981). Mycotoxin production by Chaetomium spp. and related fungi.Can J Microbiol. 27:766-72

Sigler, L. \& Verweij, P.E. (2003). Aspergillus, Fusarium, and other opportunistic moniliaceous fungi. In: Manual of clinical microbiology 8th Ed. (Murray et al.,Eds.). American Society for Microbiology, Washington. Pp. 1726-1760.

Sogonov, M.V.; Schroers, K-J.; Gams, W.; Dijksterhuis, J.; Summerbell, R.C. (2005). The Hyphomycete Teberdinia hygrophila gen. nov., sp. nov. and related anamorphs of Pseudeurotium species. Mycologia,97:695-709

Sole,, M.; Cano, J. ; Pitarch, L.B.; Stshigel, A.M.: Guarro, J. (2002). Molecular phylogeny of Gymnoascus and related genera. Stud. In Mycol. 47:141-152

Spooner, B.M.\& Butterfill, G.B. (1999). Coprophilous discomycetes from the Azores. Kew Bulletin 54: 541-560 
Stchigel, A.M.; Calduch, M. \& Zaror, L. (2002). A new species of Podospora from soil in Chile. Mycologia 94:554-558

Sugiyama, M.; Ohara,, A. \& Mikawa, T. (1999). Molecular Phylogeny of onygenalean fungi based on small subunit ribosomal DNA (SSU rDNA) sequences. Mycoscience 40:251-258

Sugiyama, M. \& Mikawa, T. (2001). Phylogenetic analysis of the non pathogenic genus Spiromastix (Onygenaceae) and related onygenalean taxa based on LSU sequences. Mycoscience 42:413421

Sugiyama, M.; Summerbel, R.C. \& Mikawa, T. (2002). Molecular phylogeny of onygenalean fungi based on small subunit (SSU) and large subunit (LSU) ribosomal DNA sequences.Stud in Mycol. 47:5-23

Suh, S-O. \& Blackwell, M. (1999). Molecular phylogeny of the cleistothecial fungi placed in Cephalothecaceae and Pseudoerotiaceae. Mycologia 91:836-848

Tisdall, J. M. \& Oades, J.M (1982). Organic matter and waterstable aggregates in soils. Journal of Soil Science 33(141-163)

Undagawa, S.\& Kobayasi,Y. (1979).Coprophilous fungi of Mexican volcano Popocatepetl. J.Jpn. Bot. 54:161-168

Valldosera M. \& Guarro J. 1988. Some coprophilous ascomycetes from Chile. - Tran. Br. mycol. Soc. 90:601-605.

Valdoserra, M. \& Guarro, J. (1992). Estudios sobre hongos coprófilos aislados en España.XVII. Recopilación de la bibliografía existente y relación de todos los ascomicetos citados. Bol. Soc. Micol. Madrid 17:39-55

van Brumelen, J. (1967). A World monograph of the genera Ascobolus and Saccobolus (Ascomycetes, Pezizales). Persoonia, Supplement 1:1-260

van Brumelen, J. (1976). Some new species of Saccobolus, Persoonia. 8:421-430

van Brumelen, J. (1980). Two species of Ascobolus new to Britain.Persoonia 11:87-92

van Brumelen, J. (1998).Reconsideration of relationships within the Thelebolaceae based on ascus ultrastructure. Persoonia 16:425469

Wang, Y-Z. (1999). The coprophilous Discomycetes of Taiwan III. Bull. Nat. Mus. Natur. Sci. 12:49-74
Wang, Y-Z; Gloer, J.B.: Scott, J.A. \& Malloch, D. (1995). Terezines A-D: new aminoacid derived bioactive metabolites from the coprophilous fingus Sporormiella teretispora. J. Nat. Prod. 58: 93-99

Wang, Y-Z. \& Brumelun, J.van. (1997). A new species of Ascobolus from Taiwan. Mycotaxon 65:443-446

Wang, Z.; Binder, M. \& Hibbett, D.S. (2005). Life history and systematics of the aquatic discomycete Mitrula (Helotiales, Ascomycota) based on cultural, morphological, and molecular studies. American Journal of Botany 92:1565-1574

Wang, Z-Y.; Binder, M.; Schoch, C.L.; Johnston, P.R.; Spatafora, J.W.; Hibbett, D.S. (2006).Evcolution of helotialean fungi (Leotiomycetes, Pezizomycotina): A nuclear rDNA phylogeny. Mol. Phylogenet. Evol. 41:295-312

Wood, S.N. \& Cooke, R.C. (1987). Use of semi-natural resource unit in experiment studies on coprophilous succession. Trans. Br. mycol. Soc.87:337-339

Wicklow, D.T. (1975). Relationships between coprophilous fungi and fecal substrates in a Colorado grassland. Mycologia 67:63-74

Wicklow, D.T. (1981). The coprophilous fungal community: A mycological system for examinin ecological ideas. In: The fungal community its organization an role in the ecosystem (Wicklow, D.T. \& Carrol, G.C.eds.), Marcel Dekker, N.york. pp.47-70

Wicklow, D.T. (1992). The coprophilous fungal community: An experimental system.In The fungal community: Its organization and role in the ecosystem (Carrol, G.C. \& Wicklow, D.T. eds.), 2nd edn,Marcel Dekker, N.York. pp. 715-728

Wicklow, D.T. \& Moore, V. (1974). Effect of incubation temperature on the coprophilous fungus succession. Trans. Br. myco. Soc. 62:411-415

Wicklow, D.T.; Angel, K. \& Lussenhop, J. (1980). Fungal community expression in lagomorph versus ruminant feces. Mycologia 72:1015-1021

Yocom,D.H. \& Wicklow ,D.T. (1980). Community differentiations along a dune succession: an eperimental approach with coprophilous fungi. Ecology 61:868-880 